\title{
Analisis Hukum Terhadap Pengenaan Pajak Ganda
}

\author{
Wirawan B. Ilyas \\ Fakultas Ekonomi Universitas Al Azhar Indonesia \\ Jln. Sisingamangaraja, Kebayoran Baru Jakarta Selatan 12110 \\ kap_wbi@cbn.net.id
}

\begin{abstract}
This research focused on the aspects of inequality and legal uncertainty due to the double taxation (double taxation) on the same object. As a result, the tax burden felt by the public will feel heavy. The research also examines the Constitutional Court ruling on the petition for the perceived tax law has imposed double taxation on an object the same tax. Analysis of the research done by looking at the tax benefit that should be used for national interests rather than the interests that are regional (sectoral) because of the potential tax on an area. Moreover, coordination among government agencies that are not effectively be an additional analysis to be more comprehensive in its discussion.
\end{abstract}

Key words: Double taxation, the constitutional court, justice and legal certainty.

\begin{abstract}
Abstrak
Penelitian ini fokus pada persoalan, pertama,mengapa dalam perundang-undangan perpajakan yang disusun pemerintah bersama DPR dalam penerapannya seringkali menimbulkan pengenan pajak ganda. Kedua, apakah pengenaan pajak ganda akan memberikan keadilan dalam pengumpulan uang pajak untuk negara. Ketiga,bagaimana cara menghindari potensi pengenaan pajak ganda agar pajak yang ditanggung masyarakat tidak semakin memberatkan. Metode yang digunakan dalam penelitian ini adalah pendekatan yuridis normatif, selain itu perundang-undangan juga dilakukan dengan pendekatan kasus. Hasil penelitian menyimpulkan: Pertama, pungutan pajak yang dilakukan semaunya oleh pemerintah dan memberi ruang penafsiran mengakibatkan timbulnya potensi pengenaan pajak ganda. Kedua,pengenaan pajak ganda akan memberikan ketidakadilan dalam pengumpulan uang pajak untuk negara. Ketiga, cara menghindari potensi pajak ganda dapat dilakukan dengan melakukan legislative review oleh DPR, dengan melakukan constitutional review ke Mahkamah Konstitusi.
\end{abstract}

Kata Kunci : Pajak ganda, mahkamah konstitusi, keadilan dan kepastian hukum. 


\section{Pendahuluan}

Sekalipun pungutan pajak yang dilakukan pemerintah sudah diatur dengan undang-undang sebagai dasar hukum yang jelas, publik tetap menilai pungutan pajak masih saja tidak memenuhi rasa keadilan dan dirasa amat memberatkan. Oleh karena pungutan pajak seringkali dilakukan atau terjadi dengan cara dua kali atas suatu objek yang sama. Dengan kata lain, atas satu objek yang sama seakan menjadi 'rebutan' pungutan pajak dengan memasukan objek pajak tersebut dalam undangundang. Ini terjadi ketika 'rebutan' objek pajak tersebut sama-sama dimasukkan dalam dua undang-undang pajak yang berbeda. Umumnya 'rebutan' terjadi antar pemerintah pusat sendiri yang berbeda kementerian pengelolaannya maupun antara pemerintah pusat dengan pemerintah daerah.

Jika demikian halnya, pastinya pungutan pajak yang terus menerus didengungkan sebagai sumber pembiayaan negara, menjadi kurang mendapat tanggapan positif dari masyarakat. Sorotan dengan nada negatif akibat pungutan pajak bersifat ganda perlu dikaji dengan baik. Pajak untuk kepentingan negara tidak seharusnya membebani masyarakat sekalipun pajak memiliki sifat memaksa dalam proses pemungutannya. ${ }^{1}$ Pungutan pajak yang dilakukan pemerintah, baik pusat maupun daerah, yang acapkali menimbulkan keresahan di masyarakat. Jika pungutan pajak bersifat ganda, berarti pungutan pajak tidak memiliki sifat hukum keadilan maupun kepastian. Padahal prinsip hukum menyatakan tidak boleh ada pungutan pajak yang dilakukan dua kali (ganda) atas suatu objek yang sama karena akan memberatkan setiap orang atau badan yang terkena pajak.

Contoh Putusan Mahkamah Konstitusi (MK) No. 77/PUU-VII/2010 mengenai pengujian atas UU No. 12/1985 tentang Pajak Bumi dan Bangunan (UU PBB), menjadi bukti betapa masyarakat menginginkan kepastian dalam pemungutan pajak. Dalam putusan MK tersebut terlihat bahwa objek pungutan yang diatur dalam UU PBB dalam pandangan pemohon pengujian UU PBB (PT. West Irian Fishing Industries, PT. Dwi Bina Utama, PT. Irian Marine Product Development, dan PT. Alfa Kurnia) seakan telah menimbulkan pungutan pajak ganda dengan pungutan yang diatur

${ }^{1}$ Sifat memaksa pajak secara tegas disebutkan dalam Pasal 1 angka 1 UU No. 6 Tahun 1983 tentang Ketentuan Umum dan tata Cara perpajakan sebagaimana telah diubah dengan UU No. 16 Tahun 2009 yang menyatakan bahwa Pajak adalah kontribusi wajib kepada negara yang terutang oleh orang pribadi atau badan yang bersifat memaksa berdasarkan undang-undang, dengan tidak mendapatkan imbalan secara langsung dan digunakan untuk keperluan negara bagi sebesar-besarnya kemakmuran rakyat. 
dalam UU No. 31/2004 tentang Perikanan. Begitupun dengan Putusan MK dengan Nomor 52/PUU-IX/2011 mengenai pengujian UU Nomor 28 Tahun 2009 tentang Pajak Daerah dan Retribusi Daerah, khususunya mengenai pajak hiburan berupa permainan golf yang diatur dalam Pasal 42 ayat (2) UU No. 28/2009 tentang Pajak Daerah dan Retribusi Daerah.

Dua contoh putusan MK tersebut menunjukkan bahwa potensi pajak daerah cenderung timbul di dalam UU berkaitan dengan pungutan pajak atau pungutan lain yang sejenis dengan pungutan pajak. Jika demikian, maka langkah yang dilakukan masyarakat yang merasa kepentingan konstitusional dirugikan, wajar diberikan apresiasi dengan mengambil langkah pengujian UU ke MK. Disini terlihat bahwa kesadaran hukum masyarakat yang terkena pungutan pajak melakukan langkah hukum menjadi cermin kesadaran hukum yang cukup tinggi. Ketimbang melakukan protes-protes yang "tidak" atau "kurang" didengar oleh penyusun UU, langkah hukum pengujian UU ke MK menjadi cara tepat yang perlu ditiru semua pihak.

\section{Rumusan Masalah}

Berdasarkan uraian di atas, rumusan masalah yang dapat dikemukakan adalah sebagai berikut : pertama, mengapa dalam perundang-undangan perpajakan yang disusun pemerintah bersama DPR dalam penerapannya seringkali menimbulkan pengenan pajak ganda ? kedua, apakah pengenaan pajak ganda akan memberikan keadilan dalam pengumpulan uang pajak untuk negara ? ketiga, bagaimana cara menghindari potensi pengenaan pajak ganda agar pajak yang ditanggung masyarakat tidak semakin memberatkan?

\section{Tujuan Penelitian}

Berangkat dari rumusan masalah diatas, maka penelitian ini bertujuan : 1. untuk menjelaskan latar belakang pengaturan timbulnya pengenaan pajak ganda dalam perundang-undangan perpajakan serta adanya ruang interpretasi dalam hal pungutan pajak yang berpotensi dikenakan pajak ganda. 2. untuk memberikan pemahaman persoalan keadilan dalam hal terjadinya pungutan pajak ganda yang terjadi dalam perundangan perpajakan. 3. untuk menjelaskan bagaimana menghilangkan potensi pengenaan pajak ganda agar masyarakat (Wajib Pajak) tidak semakin berat dalam melaksanakan kewajiban perpajakannya untuk negara. 


\section{Metode Penelitian}

Metode pendekatan yang digunakan dalam penelitian ini adalah yuridis normatif yang menggunakan bahan hukum primer, ${ }^{2}$ terutama mengenai perundangundangan di bidang perpajakan, khususnya UU Nomor 8 Tahun 1983 tentang Pajak Pertambahan Nilai Barang dan Jasa dan Pajak Penjualan Atas Barang Mewah (selanjutnya disebut UU PPN) yang telah diubah dengan UU No. 42 Tahun 2009; UU Nomor 28 Tahun 2009 tentang Pajak Daerah dan retribusi Daerah (selanjutnya disebut UU PDRD).

Selain itu digunakan juga bahan hukum sekunder yang memberikan penjelasan mengenai bahan hukum primer, berupa buku-buku perpajakan serta berbagai informasi lain yang diperoleh dari artikel, press release, media massa. Pendekatan penelitian selain dilakukan dengan menggunakan pendekatan undang-undang juga dilakukan dengan pendekatan kasus di bidang perpajakan yang telah diputus berdasarkan putusan dari lembaga Mahkamah Konstitusi (MK).

Dokumen lain yang digunakan dalam penelitian ini adalah perundangundangan yang mendukung terkait permasalahan pungutan pajak yang dikelola pemerintah daerah antara lain UU No. 32 Tahun 2004 tentang Pemerintahan Daerah, UU No. 33 Tahun 2004 tentang Perimbangan Keuangan antara Pemerintah Pusat Dan Pemerintah Daerah serta UU lainnya.

\section{Hasil Penelitian dan Pembahasan}

Pengenaan pajak ganda yang terjadi dalam praktik pungutan pajak tentu menjadi persoalan serius yang perlu dilakukan kajian agar pungutan pajak tidak memberatkan masyarakat. Seperti penulis uraikan di bagian pendahuluan, Mahkamah Konstitusi (MK) telah membuat putusan terkait adanya persoalan pengenaan pajak ganda baik pungutan pajak yang pengelolaannya dilakukan oleh pemerintah pusat maupun pungutan pajak yang pengelolaannya dilakukan oleh pemerintah pusat dan bersinggungan dengan pajak yang dikelola oleh pemerintah daerah. Contohnya adalah Putusan MK Nomor 52/PUU-IX/2011 mengenai pengujian UU Nomor 28 Tahun 2009 tentang Pajak Daerah dan Retribusi Daerah.

${ }^{2}$ Soerjono Soekanto dan Sri Mamudji, Penelitian Hukum Normatif, Suatu Tinjauan Singkat, Cetakan kedua, CV. Rajawali, Jakarta, hlm. 14. 
Secara spesifik jenis pajak yang dimohonkan adalah pajak hiburan berupa permainan golf yang diatur dalam Pasal 42 ayat (2) huruf g. ${ }^{3}$

Dalam analisis penulis pajak hiburan berupa permainan golf telah menimbulkan pungutan pajak ganda dengan pengaturan pajak yang diatur dalam UU No. 42/ 2009 tentang Pajak Pertambahan Nilai atas Barang dan Jasa dan Pajak Penjualan Atas Barang Mewah (UU PPN). Mengapa bisa terjadi demikian ? Hal ini tidak lain dikarenakan pemerintah kurang peka melihat simpul-simpuil potensi terjadinya pajak ganda yang akan memberatkan masyarakat ketika menyusun suatu undangundang khususnya pengaturan mengenai suatu objek pajak yang akan dikenakan pajak. Akhirnya MK membatalkan permainan golf menjadi bagian dari pajak hiburan. Dengan demikian atas permainan golf tidak lagi menjadi objek pajak hiburan. Pemerintah daerah pun tidak boleh memungut pajak permainan golf kepada pengusaha golf.

Tidak tertutup kemungkinan akan ada lagi permohonan pengujian UU jika praktek pungutan pajak masih memberi ruang cukup besar terjadinya pajak ganda. Kalau pajak dirasakan amat memberatkan masyarakat, maka langkah hukum yang dilakukan membuktikan bahwa masyarakat telah memiliki kesadaran hukum cukup tinggi akan hak dan kewajibannya dalam hal pungutan pajak. Kita tentu perlu memberi apresiasi jika kesadaran hukum atas pungutan pajak terus meningkat.

Selain dikenakan pajak daerah, pajak hiburan "cenderung" bisa juga dikenakan pajak pusat berdasarkan Undang-Undang Nomor 42 Tahun 2009 tentang Pajak Pertambahan Nilai Barang dan Jasa dan Pajak Penjualan Atas Barang Mewah (UU PPN). Hal ini bisa terjadi oleh karena dalam Pasal 4A ayat (3) UU PPN seakan masih memberi 'ruang' untuk mengenakannya. Selengkapnya Pasal 4A ayat (3) UU PPN menyatakan sebagai berikut: "Jenis jasa yang tidak dikenai Pajak Pertambahan Nilai adalah jasa tertentu dalam kelompok jasa sebagai berikut: (a) jasa pelayanan kesehatan medik; (b) jasa pelayanan sosial; (c) jasa pengiriman surat dengan perangko; (d) jasa keuangan; (e) jasa asuransi; (f) jasa keagamaan; (g) jasa pendidikan; (h) jasa kesenian dan hiburan; ( $i$ ) jasa penyiaran yang tidak bersifat iklan; (j) jasa angkutan umum di darat dan di air serta jasa angkutan udara dalam negeri yang menjadi bagian yang tidak terpisahkan dari jasa angkutan udara luar negeri;

\footnotetext{
${ }^{3}$ Pasal 42 selengkapnya berbunyi : ayat (1) Objek Pajak Hiburan adalah jasa penyelenggaraan hiburan dengan dipungut bayaran.; ayat (2) Hiburan sebagaimana dimaksud pada ayat (1) adalah : a. tontonan film; b. pagelaran kesenian, musik, tari, dan/atau busana; c. kontes kecantikan, binaraga, dan sejenisnya; d. pameran; e. diskotik, karaoke, klab malam, dan sejenisnya; f. sirkus, akrobat, dan sulap; g. permainan bilyar, golf, dan boling; h. pacuan kuda, kendaraan bermotor, dan permainan ketangkasan; i. panti pijat, refleksi, mandi uap/spa, dan pusat kebugaran (fitness center); dan j. pertandingan olahraga.
} 
(k) jasa tenaga kerja; (l) jasa perhotelan; (m) jasa yang disediakan oleh pemerintah dalam rangka menjalankan pemerintahan secara umum; (n) Jasa penyediaan tempat parkir; (o) Jasa telepon umum dengan menggunakan uang logam; ( $p$ ) Jasa pengiriman uang dengan wesel pos; dan (q) Jasa boga atau katering.

Pada intinya ketentuan tersebut menyatakan bahwa jasa kesenian dan hiburan termasuk jenis jasa yang tidak dikenakan PPN. Lalu, penjelasannya menyebutkan bahwa jasa kesenian dan hiburan meliputi semua jenis jasa yang dilakukan oleh pekerja seni dan hiburan. Persoaannya, apakah ketentuan ini sudah jelas dan tidak menimbulkan potensi timbulnya pajak ganda ? Dalam amatan penulis, ternyata potensi pajak ganda timbul dari kedua UU pajak diatas (UU PDRD dan UU PPN). Contoh konkritnya terlihat dengan diajukannya pengujian UU PDRD ke MK oleh Asosiasi Pemilik Lapangan Golf Indonesia serta sejumlah pengusaha lapangan golf yang terdaftar dengan Perkara Nomor 52/PUU/IX/2011.

Para pengusaha di bidang golf tentu menyadari bahwa langkah yang dilakukannya tidak lain dimaksudkan agar tidak terjadi pajak ganda atas permainan golf yang selama ini sudah menjadi objek PPN. Bagi pengusaha golf, terbitnya UU PDRD menimbulkan pajak ganda yang amat memberatkan. Selain permainan golf, sebenarnya permainan bilyar dan boling yang juga diatur dalam Pasal 42 ayat (2) huruf g UU PDRD pastinya tidak tertutup kemungkinan terkena pajak ganda. Bahkan beberapa jenis pajak hiburan lain yang diatur dalam Pasal 42 ayat (2) huruf i UU PDRD seperti panti pijat, refleksi, mandi uap, dan pusat kebugaran (fitness center) berpotensi terjadi pajak ganda dengan UU PPN.

Setelah permainan golf tidak lagi menjadi objek pajak sesuai Putusan MK, lalu bagaimana halnya dengan permainan bilyar dan bowling ? Apakah kedua jenis permainan tersebut tetap menjadi objek pajak ? Jawabannya, tentu tetap menjadi objek pajak daerah. Oleh karena MK tidak memutuskan permohonan terkait dengan permainan bilyar dan bowling. Menurut penulis, besar kemungkinan pada suatu waktu pengusaha atas permainan bilyar dan boling juga akan melakukan pengujian atas persoalan yang sama dengan pengusaha golf, jika atas permainan bilyar dan boling juga dikenakan PPN (karena akan terkena pajak ganda dengan objek pajak dalam UU PDRD).

Persoalannya sekarang apakah bilyar dan boling akan terkena PPN berdasarkan UU No. 42 Tahun 2009 ? Jika ditelusuri bunyi ketentuan Pasal 4A ayat (3) huruh h UU PPN, dinyatakan bahwa jasa kesenian dan hiburan tidak dikenakan PPN. Lalu, 
penjelasannya menegaskan bahwa "jasa kesenian dan hiburan meliputi semua jenis jasa yang dilakukan oleh pekerja seni dan hiburan". Dengan kata lain, bilyar dan boling tidak termasuk dalam jenis jasa yang tidak terkena PPN. Jadi bilyar dan boling tetap terkena PPN karena tidak dilakukan oleh pekerja seni dan hiburan. Padahal bilyar dan boling juga merupakan permainan olahraga seperti dinyatakan pihak Kementerian Pemuda dan Olahraga. ${ }^{4}$ Dengan demikian dapat disimpulkan bahwa atas bilyar dan boling berpotensi terkena pajak ganda baik dalam UU PPN maupun dalam UU PDRD.

Dalam perkembangannya saat ini memang diketahui bahwa pungutan pajak kepada pengusaha bilyar dan boling belum atau tidak seheboh permainan golf, sehingga belum tampak keberatan yang dirasakan oleh para pengusaha permainan bilyar dan boling. Tidak tertutup kemungkinan satu waktu akan dirasakan berat, jika pemda tetap memungut pajak hiburan atas permainan bilyar dan boling atas dasar UU PDRD No. 28 Tahun 2009 (karena tidak dibatalkan oleh MK) serta terkena PPN yang dipungut oleh pemerintah pusat cq. Direktorat Jenderal Pajak atas dasar UU PPN Nomor 42 Tahun 2009.

Terjadinya pajak ganda tersebut umumnya disebabkan pengenaan pajak dalam UU PPN yang mengandung prinsip 'negatif list'. Prinsip dalam UU PPN seakan memberi ruang amat besar mengenakan jenis pajak selain yang disebutkan (list) dalam UU PPN. Dengan kata lain, prinsip negatif list memberikan kesempatan bagi fiskus (aparat pajak) mengenakan pajak atas jenis jasa selain yang disebutkan dalam UU PPN. Pajak golf adalah contoh riil yang amat jelas timbulnya pungutan pajak ganda.

Terdapat dua hal lagi yang juga menarik untuk dikaji yaitu ketentuan mengenai Pajak Restoran yang diatur dalam Pasal 37 ayat (1) UU PDRD serta ketentuan Pasal

\footnotetext{
${ }^{4}$ Dinyatakan oleh Faisal Abdulah dari Kementerian Pemuda dan Olahraga sebagai saksi dari Pemohon, dalam Putusan MK No. 52/PUU-IX/2011 “bahwa cabang olahraga biliar, golf dan bowling merupakan anggota Komite Olahraga Nasional di Indonesia yang mempunyai tugas dan bertanggung jawab melakukan pembinaan dan pengembangan terhadap atlet-atlet biliar, golf, dan bowling yang merupakan olahraga prestasi, sehingga dapat meraih prestasi (hal 39). Selain itu juga dinyatakan "Dalam perspektif UU No. 3 tentang Sistem Keolahragaan Nasional, biliar, golf, dan bowling dapat dapat dikategorikan dalam ruang lingkup olahraga prestasi dan bukan sebagai jenis hiburan karena dengan telah berdirinya Persatuan Olahraga Biliar Seluruh Indonesia pada tanggal 9 Oktober 1953, Persatuan Golf Indonesia pada tanggal 8 April 1966, dan Persatuan Bowling Indonesia pada tanggal 19 November 1970, maka POBSI, PGI dan PBI merupakan induk organisasi cabang olahraga yang mempunyai tanggung jawab dalam hal pengembangan dan pembinaan olahraga biliar, golf, bowling, hal ini sesuai dengan ketentuan Pasal 27, "Pembinaan dan pengembangan olahraga prestasi dilaksanakan dengan memberdayakan perkumpulan olahraga, menumbuhkembangkan sentra pembinaan olahraga bersifat nasional dan daerah, menyelenggarakan kompetisi secara berjenjang dan berkelanjutan. (hal 40).
} 
42 ayat (2) huruf j UU PDRD mengenai pajak hiburan berupa pertandingan olahraga. Mari kita bahas kedua objek pajak tersebut, apakah juga berpotensi terkena pajak ganda. Pasal 37 ayat (1) UU PDRD menyatakan bahwa objek pajak restoran adalah pelayanan yang disediakan oleh restoran. Awalnya Pajak Restoran bisa berpotensi menimbulkan pajak ganda dengan ketentuan Pasal 4A ayat (2) huruf c UU PPN. Pasal 4A ayat (2) huruf c UU PPN menyatakan bahwa "makanan dan minuman yang disajikan di hotel, restoran, rumah makan, warung, dan sejenisnya, meliputi makanan dan minuman baik yang dikonsumsi di tempat maupun tidak, termasuk makanan dan minuman yang diserahkan oleh usaha jasa boga atau katering, tidak dikenai PPN". Namun, potensi pajak ganda menjadi hilang ketika kita membaca penjelasan dari Pasal 4A ayat (2) huruf c tersebut bahwa ketentuan ini dimaksudkan untuk menghindari pengenaan pajak ganda karena sudah merupakan objek pengenaan pajak daerah (huruf tebal dari penulis). Dengan kata lain, potensi timbulnya pajak ganda atas objek pajak restoran menjadi sulit untuk direalisasikan.

Sekarang, bagaimana halnya dengan pertandingan olahraga ? Seperti diketahui ada banyak jenis pertandingan olahraga, seperti pertandingan sepakbola, tenis lapangan, tenis meja, sepak takraw, bola basket, futsal, dan permainan olah raga lainnya. Apakah atas pertandingan olahraga tersebut merupakan objek pajak daerah dan objek PPN ? Dalam analisis penulis, atas jenis permainan-permainan tersebut bisa menimbulkan dua pendapat. Pertama, tidak akan dikenakan pajak daerah (bukan objek pajak daerah) karena tidak secara tegas disebutkan dalam UU (prinsip positif list) seperti halnya golf, boling dan bilyar. Namun pendapat kedua, atas pertandingan olahraga yang disebutkan diatas, apapun nama jenis olahraganya, akan terkena pajak daerah (objek pajak daerah) sepanjang digolongkan sebagai kelompok olahraga yang dipertandingkan.

Sedangkan dari sudut UU PPN, atas berbagai macam jenis olahraga dengan nama apapun, bukan merupakan objek PPN dan tidak akan dikenakan PPN. Hal ini secara tegas dinyatakan dalam ketentuan Pasal 4A ayat (3) huruf b dan penjelasannya bahwa atas jasa pelayanan sosial yang meliputi jasa di bidang olahraga tidak dikenakan PPN, kecuali yang bersifat komersial. Adanya kata-kata "kecuali yang bersifat komersial" seringkali memberikan penafsiran berbeda dalam mengartikan jenis olahraga. Oleh karena dalam kenyataannya terlihat bahwa sekalipun olahraga dimaksudkan untuk meraih prestasi, tetapi ada kecenderungan bahwa dibalik meraih prestasi juga bermaksud mencari keuntungan yang sifatnya 
komersial. Disinilah pentingnya penyusun UU memberikan penjelasan secara tegas, bukan hanya dengan kata "cukup jelas".

Kriteria komersial pada jenis PPN dalam pandangan Untung Sukardji sebenarnya tidak dikenal. Istilah komersial yang sebenarnya menjadi hak milik mutlak Pajak Penghasilan (PPh) selaku jenis pajak atas kegiatan bisnis. Sebagai pajak konsumsi, faktor komersial dan non komersial dari kegiatan usaha yang dilakukan oleh Pengusaha Kena Pajak bukanlah faktor yang relevan bagi PPN. ${ }^{5}$ Penggunaan kriteria komersial tampaknya terus dipakai oleh penyusun Undang-Undang. Penggunaan kriteria komersial demikian merupakan kekeliruan yang seharusnya tidak terulang. ${ }^{6}$

Pada akhirnya, kita pun perlu memahami bahwa apapun bentuk pungutan pajak yang dilakukan oleh pemerintah (baik pemerintah pusat maupun pemerintah daerah) kepada masyarakat (wajib pajak) tidak boleh bertentangan dengan prinsip keadilan, kepastian hukum dan kesamaan kedudukan hukum. Hal itu pula yang dinayakan MK dalam Putusannya Nomor 52/PUU-IX/2011 bahwa pengenaan pajak (termasuk pajak daerah) tidak boleh dilakukan hanya karena adanya kebutuhan untuk pembangunan demi kemaslahatan umum sehingga mencari orang atau bidang pelayanan jasa yang memiliki kemampuan membayar.

\section{Simpul Potensi}

Sejak terbitnya putusan MK yang menghapus adanya pajak permainan golf dalam UU PDRD, menunjukkan bahwa simpul potensi terjadinya pungutan pajak ganda masih terbuka luas untuk objek pajak lain. Masyarakat yang berusaha di bidang permainan bilyar dan boling adalah dua contoh simpul potensi kemungkinan dilakukan permohonan uji UU ke MK. Kalau begitu, dalam kajian penulis paling tidak tiga hal perlu dilakukan oleh pihak pemerintah maupun DPR. Pertama, perlunya memperkuat koordinasi penyusunan perundang-undangan di bidang perpajakan agar tidak terjadi pola pikir mementingkan kepentingan sektoral. Lemahnya koordinasi yang dilakukan pemerintah bersama DPR terwujud dari produk undang-undang yang banyak dilakukan pengujian ke MK.7 Pemerintah

\footnotetext{
${ }^{5}$ Untung Sukardji, Sebuah Analisis Konstruktif Perubahan Undang-Undang pajak Pertambahan Nilai 1984 dengan UU Nomor 18 Tahun 2000, PT. RajaGrafindo Persada, Jakarta, 2001, hlm. 28.

${ }^{6}$ Ibid., hlm. 29.

${ }^{7}$ Halaman 44 dari PUT MK No. 52/PUU-IX/2011 menyatakan dengan tegas sbb "Kementerian Pemuda dan
} 
seharusnya menyadari kondisi demikian terlebih dalam hal pungutan pajak yang selalu dikatakan bahwa pajak menjadi nadi bergeraknya ekonomi masyarakat.

Mari kita lihat isi (content) dari UU No. 28 Tahun 2009 tentang Pajak Daerah dan Retribusi Daerah (UU PDRD). Disini terlihat pemerintah bersama DPR kurang serius memperhatikan keterkaitan antara UU PDRD dengan perundang-undangan pajak lainnya seperti dalam UU Pajak Pertambahan Nilai yang pengelolaan pajaknya dilakukan oleh Direktorat Jenderal Pajak Kementerian Keuangan. Pasal 42 UU PDRD memberi contoh kuat karena isi secara keseluruhan tampak cenderung memberi simpul terjadinya potensi pajak ganda dengan pengertian objek pajak yang diatur dalam Pasal 4A UU No. 42 Tahun 2009 tentang pajak Pertambahan Nilai (PPN). Prinsip pengenaan pajak berdasarkan asas 'negatiflist' dalam UU PPN memberi ruang terjadinya pajak ganda dengan pajak hiburan. Prinsip negatif list dalam UU PPN seakan tidak sejalan dengan prinsip closed-list yang dianut dalam UU PDRD.

Yang kedua, pemerintah perlu memperluas intensitas keterlibatan ahli di perpajakan dalam penyusunan UU. Produk UU PDRD terkesan kurang memberi kesempatan luas kepada berbagai pakar bidang perpajakan. Kalimat "yang penting undang-undangnya jadi dulu, soal di lapangan adalah soal lain", acapkali menjadi penilaian sekaligus kalimat sindiran kepada penyusun undang-undang. Dan ketiga, perlu memperkuat proses politik hukum penyusunan undang-undang bidang perpajakan. Publik masih menilai kuat kalau proses politik penyusunan UU PDRD masih banyak didominasi pada kepentingan kelompok (daerah) tertentu, bukan kepentingan nasional yang menjadi tujuan bersama. Tjip Ismail, dalam bukunya berjudul "Pengaturan Pajak Daerah di Indonesia", menekankan bahwa kadang-kadang sensitivitas politik menyebabkan terbawanya fokus pembahasan kepada isu-isu spesifik seperti apakah tanah harus dipajaki atau apakah air bersih harus dikenakan pungutan, atau fokus juga bisa terbawa kepada kepentingan kelompok-kelompok tertentu, seperti pegawai negeri dan pengusaha. ${ }^{8}$

Olahraga tidak terlibat dalam pembahasan antar kementerian yang merupakan prasyarat penyusunan suatu rancangan undang-undang, apabila terdapat muatan materi yang berkait dengan pengaturan kepentingan sektor seperti halnya penggolongan cabang olahraga biliar, golf, dan bowling yang notabene merupakan kewenangan Kementerian Negara Pemuda dan Olahraga Republik Indonesia sewajarnya dilibatkan, sehingga dapat memberikan saran dan pertimbangan pada waktu pembahasan rumusan dan pengkategorian cabang olahraga sebagai objek pajak hiburan ke dalam produk perundang-undangan.

${ }^{8}$ Tjip Ismail, Pengaturan Pajak Daerah di Indonesia, diterbitkan oleh Departemen Keuangan Republik Indonesia, Badan Pengkajian Ekonomi Keuangan dan Kerjasama Internasional, Pusat Evaluasi Pajak dan Retribusi Daerah, Cet I, Jakarta, 2005, hlm. 200. 
Pengalihan pengelolaan Pajak Bumi dan Bangunan (PBB) ke daerah yang diatur dalam Pasal 2 ayat (2) huruf j seakan menjadi bukti nyata kepentingan kedaerahan mengalahkan kepentingan nasional. Kentalnya kepentingan otonomi daerah seakan menjadi tujuan praktis menggali potensi pajak di wilayahnya masing-masing. Daerah-daerah lain yang merasa dirugikan kepentingannya sebenarnya bisa saja melakukan pengujian Pasal 2 ayat (2) huruf j ke Mahkamah Konstitusi sesuai Pasal 51 UU MK No. 24 Tahun 2003. Artinya, pemerintah daerah selaku pemohon bisa meminta agar pengelolaan PBB tetap dilakukan Pemerintah Pusat supaya memberikan keadilan bagi daerah-daerah lain yang potensi pajaknya kecil.

Tujuan praktis menggali potensi pajak lebih kentara lagi jika kita lihat besaran tarif yang diatur. Tarif pajak hiburan yang diatur dalam Pasal 45 ayat (1) UU PDRD, misalnya, disebutkan mencapai angka sampai $35 \%$ (tiga puluh lima persen). Besaran ini menjadi sinyalemen sekaligus indikator kuat yang mudah ditebak kalau otonomi daerah lebih diutamakan. Bahkan, besaran tarif pajak hiburan berupa pagelaran busana, kontes kecantikan, diskotik, karaoke, permainan ketangkasan, panti pijat, dan mandi uap/spa, bisa mencapai tarif 75 \% (Pasal 45 ayat 2). Jika demikian, tidak tertutup kemungkinan Pemerintah Daerah akan mengenakan tarif pajak tertinggi untuk kepentingan otonomi daerahnya masing-masing dengan alasan hal itu dimungkinkan oleh Undang-undang. Kalau begitu jadinya, penulis meyakini investasi yang diharapkan pasti sulit masuk ke daerah karena terganjal tarif pajak besar.

Otonomi daerah yang memberi keleluasaan atau kewenangan penuh kepada daerah acapkali menimbulkan dilema dalam hal pungutan pajak. Penjelasan UU PDRD sendiri sudah mengakui dengan menyatakan banyak pungutan daerah yang mengakibatkan ekonomi biaya tinggi karena tumpang tindih dengan pungutan pusat dan merintangi arus barang dan jasa antar daerah.

Kalau begitu, simpul persoalan potensi pajak ganda adalah persoalan serius yang memerlukan pemikiran bersama. Simpul potensi pajak ganda tidak boleh dibiarkan terjadi. DPR pun bisa mengambil langkah melakukan legislative review agar terjadi keselarasan semua produk perundang-undangan di bidang perpajakan. Jika itu tidak terjadi, maka kesadaran hukum masyarakat melakukan pengujian (konstitutional review) ke MK menjadi langkah tepat dan bijak. Langkah ini pastinya akan membuka mata kita sekaligus menilai tingginya kesadaran hukum masyarakat memperoleh keadilan dalam pungutan pajak. 
Memang diakui bahwa persoalan pajak - termasuk persoalan simpul potensi pajak ganda - bisa dilihat dari kajian atau aspek ekonomi maupun politik. Namun, persoalannya akan lebih lengkap jika juga ditilik dari aspek hukum sambil mengutip teori hukum dari Talcott Parsons yang menekankan bahwa hukum itu mekanisme integrasi. ${ }^{9}$ Artinya, aspek ekonomi maupun politik memiliki tugasnya masingmasing yang merupakan realitas yang terjadi di masyarakat. Aspek politik bersangkut paut dengan kekuasaan dan kewenangan yang tugasnya adalah pendayagunaan kekuasaan dan kewenangan untuk mencapai tujuan.

Sedangkan ekonomi menunjuk pada sumber daya materil yang dibutuhkan untuk menopang hidup sistem. Tugas sub sistem ekonomi adalah menjalankan fungsi adaptasi berupa kemampuan menguasai sarana-sarana dan fasilitas untuk kebutuhan sistem. Untuk menata keserasian dan gerak sinergis dari kedua aspek tersebut, maka aspek hukumlah yang dapat menjamin hidup matinya suatu masyarakat. Inilah fungsi integrasi sebagai fungsi dari hukum yang dikemukakan Parsons.

Mengacu pada dasar teori Parsons diatas, maka simpul potensi pajak ganda sebaiknya dikaji dari aspek hukum, bukan pada aspek penerimaan pajak semata apalagi aspek politik. Pungutan pajak yang berpotensi menimbulkan pungutan pajak ganda tidak boleh lagi terulang karena akan memberikan ketidakpastian dan memberatkan masyarakat. Selain itu, kemungkinan timbulnya potensi pajak ganda pastinya telah menyalahi asas kesesuaian dengan tujuan. ${ }^{10}$ Artinya, kesesuaian dengan tujuan dilakukannya pemungutan pajak harusnya disadari pada saat dibuatnya undang-undang (dalam hal ini UUPDRD), sehingga kesadaran mengenai mengenai tujuan pungutan pajak akan menjadi landasan yang perlu diperhatikan dalam pembentukan undng-undang pajak. ${ }^{11}$

Kiranya perlu menjadi perhatian bahwa pembentukan hukum (UU yang baik) tidak dapat dilepaskan dari tujuan yang akan dicapai oleh hukum itu sendiri. Kesesuaian dengan maksud dibentuknya hukum dan kepastian hukum mempunyai hubungan yang erat, sekalipun kadang-kadang dalam praktek antara keduanya sering terjadi benuran satu sama lain. Kesesuaian dengan tujuan kadang

\footnotetext{
${ }^{9}$ Bernard L. Tanya, Yoan N. Simanjuntak, Markus Y. Hage., Teori Hukum, Strategi Tertib Manusia Lintas Ruang dan Generasi, Genta Publishing, Cet. III, Yogyakarta, 2010, hlm. 152.

${ }^{10}$ Rochmat Soemitro, Asas-Asas Hukum Perpajakan, Badan Pembinaan Hukum Nasional Departemen Kehakiman, Jakarta, 1991, hlm. 28-29

${ }^{11}$ Ibid.
} 
dikorbankan untuk tujuan kepastian hukum dan kadang kepastian hukum yang dikorbankan. Khusus terhadap persoalan potensi pajak ganda, perlu analisis yang lebih komprehensif agar tidak hanya tujuan kepastian hukum yang diinginkan tetapi juga tujuan kesesuaian dengan tujuan khususnya tujuan yang tidak memberatkan Wajib Pajak yang akan terkena pajak.

\section{Pajak Ganda dan Otonomi Daerah}

Persoalan pengenaan (pungutan) pajak ganda antara jenis pajak yang dikelola pemerintah pusat dengan pajak yang dikelola pemerintah daerah, tentu tidak terlepas dari persoalan otonomi daerah yang terus menjadi perdebatan di masyarakat. Sejak era sentralisasi pemerintahan jaman orde baru tumbang 1998, era otonomi daerah terus digencarkan oleh berbagai kalangan. Kewenangan untuk mengatur dan mengurus rumah tangga (daerah) masing-masing secara terus menerus semakin menguat. Hal ini dibuktikan dengan diterbitkannya UU No. 32 Tahun 2004 tentang Pemerintahan Daerah, yang memberikan pengertian sangat jelas tentang otonomi daerah. Otonomi daerah adalah hak, wewenang, dan kewajiban daerah otonom untuk mengatur dan mengurus sendiri urusan pemerintahan dan kepentingan masyarakat setempat sesuai dengan peraturan perundang-undangan. ${ }^{12}$

Dalam mengatur dan mengurus rumah tangga daerah, diperlukan sumber pendapatan agar keuangan daerah bisa berkelanjutan yang tidak lain diperoleh dari pajak dan retribusi. Parameter yang menjadi ukuran keberhasilan otonomi daerah ini berasal dari sumber-sumber yang dikelola oleh pemerintah daerah itu sendiri (local source).$^{13}$ Pendapatan yang utama adalah pajak daerah, retribusi daerah dan hasil-hasil badan usaha yang dimiliki daerah. Pajak daerah dalam rangka pelaksanaan desentralisasi fiskal diharapkan mampu memberikan penerimaan yang signifikan dalam membiayai tanggung jawab fiskalnya. ${ }^{14}$ Keinginan melakukan demikian dalam amatan penulis harus tetap berlandaskan pada pandangan melihat secara komphehensif potensi pajak dan objek pajak yang diatur harus jelas agar tidak menimbulkan keresahan dan beban di masyarakat.

Pelaksanaan otonomi daerah bisa dipahami selain harus dilakukan berlandaskan pada acuan hukum, juga merupakan implementasi dari tuntutan

\footnotetext{
${ }^{12}$ Pasal 1 angka 5 UU No. 32 Tahun 2004 tentang Pemerintahan Daerah.

${ }^{13}$ Ani Sri Rahayu, Pengantar Kebijakan Fiskal, Penerbit Bumi Aksara, Jakarta, 2010, hlm. 117.

${ }^{14}$ Ibid., hlm. 118.
} 
globalisasi yang harus diberdayakan dengan cara memberikan daerah kewenangan yang lebih luas, lebih nyata dan bertanggung jawab, terutama dalam mengatur, memanfaatkan dan menggali sumber-sumber potensi yang ada di daerahnya masing-masing. ${ }^{15}$ Ketika berbicara menggali sumber-sumber potensi yang ada di daerahnya masing-masing inilah, Pemerintah (Kementerian Dalam Negeri) dalam pelaksanaannya kurang melakukan koordinasi dengan pemerintah pusat, khususnya sumber-sumber potensi terkait objek pajak yang menjadi sumber pembiayaan daerah.

Itu terbukti dengan contoh pajak permainan hiburan yang tidak dilakukan koordinasi dengan Kementerian yang membidangi bidang olahraga (Kemenpora). Artinya, persoalan pungutan pajak terkait otonomi daerah sejatinya memerlukan koordinasi yang sangat kuat. Bila perlu Presiden dan Wakil Presiden ikut memantau langsung tiap perundang-undangan yang didalamnya mengatur persoalan pajak, agar tercipta satu koordinasi yang baik lintas Kementerian yang ada.

Padahal, untuk suksesnya otonomi daerah diperlukan kewenangan yang merupakan modal dasar untuk melakukan pembangunan daerah. Satu hal fungsi yang diperlukan yang amat penting adalah memberikan fasilitas segala bentuuk kegiatan di daerah, terutama dalam bidang perekonomian. Misalnya dengan menawarkan fasilitas perpajakan yang merangsang penanaman modal. ${ }^{16} \mathrm{Kalau}$ pemerintah daerah mempunyai kecenderungan untuk memungut pajak, maka tidak mustahil kalangan pengusaha mencari tempat lain untuk menanamkan modalnya yang memberikan rangsangan berusaha dengan lebih baik. ${ }^{17}$

Timbulnya persoalan pungutan pajak ganda antara pemerintah pusat dan pemerintah daerah seringkali disebabkan kurang fahamnya penyusun UU dalam menentukan objek pajak yang harus dicantumkan. Padahal, kewenangan untuk memungut pajak selain harus diatur dalam UU Pajak Daerah juga harus memenuhi kriteria-kriteria tertentu, antara lain (a) pajak tersebut harus tepat sebagai pajak daerah khususnya berkaitan dengan kegiatan ekonomi dari daerah; (b) pajak tersebut harus dapat diterima secara politis baik pada tingkat nasional ataupun daerah; dan (c) dasar pengenaan pajak tersebut tidak boleh tumpang tindih dengan dasar pengenaan pajak pemerintah pusat atau daerah lainnya atau tumpang tindih dengan

\footnotetext{
${ }^{15}$ http://id.wikipedia.org/wiki/Otonomi_daerah, diunduh tanggal 25 Juli 2012.

${ }^{16}$ Syaukani HR, Afan Gaffar, dan M Ryaas Rasyid, Otonomi Daerah Dalam Negara Kesatuan, Penerbit, Pustaka Pelajar, Jogyakarta, Cet I, 2002, hlm. 219.

${ }^{17}$ Ibid.
} 
biaya perijinan yang sebenanrnya lebih bersifat pajak (pajak berganda). ${ }^{18}$ Bahkan kebijakan mengenai objek pajak daerah dan administrasi pajak yang seragam antar daerah amat diperlukan untuk mempermudah wajib pajak memenuhi kewajiban perpajakannya. ${ }^{19}$

Lebih jelas apabila kita perhatikan ketentuan Pasal 10 ayat (3) huruf e UU Pemerintahan Daerah bahwa urusan fiskal (pajak) menjadi urusan pemerintah pusat. Akan tetapi mengapa pemerintah daerah dalam UU PDRD nya kurang memperhatikan sinkronisasi dalam hal pungutan pajak. Lagi-lagi penyusun UU PDRD seakan-akan hanya mementingkan kepentingan sektoral semata. Bicara pajak, sejatinya bukan bicara ego sektoral untuk kepentingan daerah. Bicara pajak adalah bicara Negara Kesatuan Republik Indonesia (NKRI). Oleh karenanya, ego sektoral mementingkan pajak untuk kepentingan daerah harus segera dihilangkan.

Sinkronisasi kepentingan pajak sebenarnya sudah tampak dalam UU No. 33 Tahun 2004 yang mengatur perimbangan keuangan antara pusat dan daerah. Artinya, pemerintah pusat akan mengatur agar pemerintah daerah yang APBD nya kurang, bisa mendapatkan tambahan dari APBN secara keseluruhan. Pola berfikir melakukan perimbangan keuangan pusat dan daerah sudah tepat. Jika suatu daerah miskin APBD-nya, daerah tersebut tetap tidak akan berkembang jika tidak ditopang dari APBN. Sebaliknya daerah yang kaya APBD-nya akan terus kaya tanpa perlu bantuan lagi. Akan tetapi sangat disayangkan, timbulnya pungutan pajak daerah dengan menegaskan objek pajak tertentu yang dikenakan pajak daerah menjadi kontraproduktif dengan aturan UU No. 33 Tahun 2004. Inilah tugas pemerintah agar dalam penyusunan jenis objek pajak tidak melihat pada kepentingan daerah semata. Apalagi atas jenis pajak yang diatur sudah terakomodir sebagai objek pajak yang diatur dalam perundang-undangan pajak lainnya yang dikelola pemerintah pusat (UU PPN dan juga UU PBB).

Seperti diketahui bahwa tujuan otonomi daerah tidak lain dimaksudkan untuk meningkatkan pelayanan dan kesejahteraan masyarakat. Ukuran keberhasilan otonomi daerrah adalah terwujudnya kehidupan yang lebih baik lebih adil dalam memperoleh penghasilan/pendapatan serta terlindungi dari rasa aman dari segala gangguan dan lingkungan hidup lebih nyaman. ${ }^{20}$ Untuk mencapai tujuan tersebut,

\footnotetext{
${ }^{18}$ Tjip Ismail, Op.Cit., hlm. 265.

${ }^{19}$ Tjip Ismail, Op.Cit., hlm. 266.

${ }^{20}$ HAW. Widjaja, Otonomi Daerah dan Daerah Otonom, Penerbit RajaGrafindo Persada, Cet I, Jakarta, 2002, hlm.
} 
pemerintah daerah perlu lebih transparan dalam memanage keuangan daerah termasuk penerimaan dari sektor pajak. Oleh karena kemandirian sistem manajemen di daerah serta distribution of income menjadi masalah yang perlu diperhatikan. ${ }^{21}$

Diakui pula bahwa memang keberhasilan otonomi daerah tidak bisa dilepaskan dari peran pajak yang menjadi sumber utama pembiayaan daerah. Faktor keuangan daerah menjadi salah satu faktor yang akan mempengaruhi pelaksanaan otonomi. ${ }^{22}$ Artinya, faktor keuangan merupakan faktor esensial dalam mengukur tingkat kemampuan daerah melaksanakan otonominya. ${ }^{23}$ Dengan demikian, persoalan keuangan daerah yang utamanya daeri sumber pajak harus tetap menjadi perhatian serius pemerintah sambil mengingat fungsi pajak untuk kesejahteraan masyarakat. Kesejahteraan masyarakat pun hanya akan mempunyai nilai lebih baik jika dalam pemungutan pajak dilakukan dengan cara adil dan berkepastian hukum serta tidak memberatkan masyarakat yang menjadi sasaran pungutan pajak.

\section{Kepastian Hukum}

Tentang pengertian kepastian hukum yang diatur dalam undang-undang pajak memang belum terdapat kesesuaian paham. Akan tetapi, arti yang pasti ialah bahwa ketentuan undang-undang tidak boleh memberikan keragu-raguan. ${ }^{24}$ Harus dapat diterapkan secara konsekuen untuk keadaan yang sama secara terus menerus. Undang-undang pajak harus disusun sedemikian rupa sehingga tidak memberikan peluang kepada siapa pun untuk memberikan interpretasi yang lain daripada yang dikehendaki oleh pembuat undang-undang. ${ }^{25}$

Namun, objek pajak yang diatur dalam UU PDRD maupun UU PPN, seringkali menimbulkan interpretasi dalam penerapannya di lapangan. Itu terbukti dengan adanya Putusan MK No. 52/PUU-IX/2011 yang memutuskan agar pajak permainan golf dinyatakan tidak berlaku. Pengusaha golf yang melakukan permohonan uji UU PDRD merasakan adanya ketidakpastian hukum akibat adanya pengenaan pajak ganda terkait pungutan pajak berupa PPN untuk objek yang sama atas jasa golf yang dilakukan oleh pengusaha golf.

\footnotetext{
${ }^{21}$ Mardiasmo, Otonomi \& Manajemen Keuangan Daerah, Penerbit Andi, Jogjakarta, 2004, hlm. 97

${ }^{22}$ Josef Riwu Kaho, Prospek Otonomi Daeerah di Negara Republik Indonesia, Identifikasi Beberapa Faktor Yang Mempengarubi Penyelenggaraannya, Penerbit RajaGrafindo Persada, Cetakan keempat, Jakarta, 1997, hlm. 123.

${ }^{23}$ Ibid.

${ }^{24}$ Rochmat Soemitro, Pajak Ditinjau Dari Segi Hukum, PT. Eresco, Cetakan kedua, Bandung, 1991, hlm. 6.

${ }^{25}$ Ibid.
} 
Kepastian hukum dalam hukum pajak (undang-undang pajak) sebaiknya tidak memberikan peluang kepada siapapun untuk memberikan penafsiran lain daripada kehendak pembuat undang-undang. Beberapa faktor yang perlu diperhatikan untuk memberikan kepastian hukum, yaitu mengenai ${ }^{26}$ (a) materi objek; (b) subjek yang tersangkut; (c) tempat; (d) waktu; (e) pendefinisian; .... dstnya sampai (j) syarat-syarat lain. Menurut penulis, kepastian objek pajak merupakan satu faktor yang amat penting guna menghilangkan potensi menafsirkan terjadinya pajak ganda. Contoh putusan MK seperti disebut diatas menjadi masukan penting agar hukum pajak menjadi satu hukum publik yang memiliki kepastian dalam penerapan pengenaan pajak bagi masyarakat.

Rochmat Soemitro menjelaskan lebih lanjut pengertian kepastian hukum dari sisi objek bahwa mengenai materi/objek harus diuraikan secara jelas dan tegas, yang tidak menimbulkan keragu-raguan dan tidak memberikan kesempatan kepada pihak lain pun untuk memberikan interpretasi lain. Dijelakan pula bahwa penggunaan bahasa dan cara menguraikan mempunyai pengaruh yang sangat besar terhadap kejelasan dan kepastian, juga penggunaan istilah yang sudah baku mempertinggi kejelasan dan kepastian hukum. ${ }^{27}$

Jika undang-undang pajak tidak berkepastian hukum, mau tidak mau akan menimbulkan berbagai macam interpretasi. Walaupun interpretasi tidak dilarang, bahkan dimungkinkan, akan tetapi sejauh mungkin hendaknya bisa diminimalisir kemungkinan terjadi interpretasi oleh berbagai pihak. ${ }^{28}$ Persoalan timbulnya pengenaan pajak ganda antara jenis pajak pusat dan jenis pajak daerah atas satu objek yang sama menunjukkan adanya ketidakpastian hukum yang merugikan masyarakat. Untuk itu, penyusun UU di bidang perpajakan tidak boleh bermainmain dalam menentukan objek pajak. Lagi-lagi koordinasi yang diinginkan berbagai pihak tidak terjadi dalam penyusunan UU PDRD di atas.

\footnotetext{
${ }^{26}$ Ibid., hlm. 7.

${ }^{27}$ Ibid.. hlm. 7.
}

${ }^{28}$ Dari berbagai macam interpretasi atau penafsiran yang ada seperti penafsiran secara sistematis, secara sosiologis, penafsiran menurut sejarah dan menurut kiasa, penulis menilai bahwa penafsiran yang dilakukan oleh Mahkamah Konstitusi dalam memutus pajak permainan golf untuk dibatalkan pungutan pajaknya adalah penafsiran yang melihat secara keseluruhan (sistematis) baik antar UU PDRD sendiri maupun antar UU PDRD dengan UU PPN serta UU Sistem Keolahragaan yang terkait dengan golf sebagai bagian dari bidang olahraga yang terdaftar di Komite Olahraga Nasional Indonesia. Bahkan penafsiran secara sosiologis menurut penulis kerap terjadi. Hal ini terlihat dengan dilibatkannya berbagai saksi dalam persidangan MK dengan menghadirkan saksi-saksi yang berkaitan langsung dengan kegiatan golf seperti saksi dari pengusaha golf dengan memberikan pertimbangan-pertimbangan sesuai dengan kenyataan yang terjadi di masyarakat pencinta atau yang suka bermain golf. Lihat hlm. 45-46 Putusan MK. 


\section{Penutup}

Dari pembahasan yang telah diuraikan diatas, dapat disimpulkan beberapa hal : 1. sudah menjadi pengetahuan bersama bahwa negara (pemerintah pusat dan daerah) membutuhkan dana untuk membangun berbagai fasilitas publik seperti jalan, jembatan, sekolah, rumah sakit, dan lainnya. Untuk itu tidak ada cara lain selain dengan cara mengumpulkan uang pajak untuk memenuhi kebutuhan pembangunan tersebut. Masih banyak infrastruktur jalan yang rusak di berbagai wilayah Indonesia, terutama di daerah-daerah yang masih terbelakang serta berbagai fasilitas sosial seperti rumah sakit, sekolah, yang belum ada. Mau tidak mau, pajak menjadi jalan keluar guna memenuhi kebutuhan berbagai macam fasilitas publik yang dibutuhkan. 2. pungutan pajak yang dilakukan pemerintah memberi kesan 'semau pemerintah melakukannya', yang mengakibatkan timbulnya potensi pengenaan pajak ganda yang bisa memberikan ketidakpastian hukum di dalam proses pungutan pajak sehari-hari. Padahal pungutan pajak harus dilakukan dengan memperhatikan keadilan, kepastian hukum serta tidak memberatkan masyarakat yang terkena pungutan pajak. 3. pungutan pajak yang diatur dalam undang-undang sejatinya tidak boleh memberikan interpretasi atau penafsiran yang bisa merugikan masyarakat. Pungutan pajak yang memberi ruang penafsiran, pastinya menimbulkan terjadinya pajak ganda. Contoh pungutan pajak hiburan berupa permainan golf yang diatur dalam UU PDRD Nomor 28 Tahun 2009 menjadi realita hukum terjadinya pungutan pajak ganda. Pajak ganda tersebut terjadi akibat adanya pungutan jenis pajak PPN yang diatur dalam UU Nomor 42 Tahun 2009 (UU PPN). 4. persoalan pungutan pajak ganda tidak hanya terjadi antar pajak daerah dengan pajak pusat, akan tetapi juga pernah terjadi karena penafsiran antara UU Perikanan dengan UU Pajak Bumi dan Bangunan. Kedua UU yang mengenakan pungutan pajak yang sama atas objek pajak yang sama pun akhirnya dibawa ke MK. Jadi tepatlah apa yang dikatakan MK dengan mengutip saksi ahli TB Eddy Mangkuprawira yang menerangkan bahwa tumpang tindih pengenaan pajak oleh dua undang-undang yang berbeda terhadap satu objek pajak berpotensi terjadi penyalahgunaan wewenang dalam pelaksanaan pungutan pajak atau abuse of power yang melahirkan stigma power to tax is the power to destroy. ${ }^{29}$

Berdasarkan kesimpulan diatas, dapat disarankan : 1. bahwa persoalan hukum terhadap potensi timbulnya pajak ganda, diharapkan DPR segera melakukan legislative

\footnotetext{
${ }^{29}$ Halaman 83 Putusan MK No. 52/PUU-IX/2011.
} 
review agar terhadap perundangan poerpajakan sehingga terjadi keselarasan antar dua undang-undang atau lebih. Jika itu tidak terjadi, langkah masyarakat (pengusaha) melakukan konstitutional review ke Mahkamah Konstitusi menjadi langkah hukum amat bijak. Langkah hukum sejatinya merupakan langkah yang patut dilakukan menuju tertib hukum dalam pungutan pajak. 2. pemerintah patut dan wajar untuk melakukan kaji ulang agar pungutan pajak sebagai sumber dana APBN maupun APBD berjalan dengan baik guna kepentingan seluruh masyarakat tentunya dengan menghilangkan simpul potensi pajak ganda. Dengan demikian akan tercipta tertib hukum dalam hal pungutan pajak sekaligus memberikan kebaikan bagi kesejahteraan bersama seperti diamanahkan konstitusi.

\section{Daftar Pustaka}

Ismail, Tjip, Pengaturan Pajak Daerah di Indonesia, Diterbitkan oleh Departemen Keuangan Republik Indonesia, Badan Pengkajian Ekonomi Keuangan dan Kerjasama Internasional, Pusat Evaluasi Pajak dan Retribusi Daerah, Cet I, Jakarta, 2005.

Mardiasmo, Otonomi E Manajemen Keuangan Daerah, Penerbit Andi, Jogjakarta, 2004.

Riwu Kaho, Josef, Prospek Otonomi Daeerah di Negara Republik Indonesia, Identifikasi Beberapa Faktor Yang Mempengaruhi Penyelenggaraannya, Penerbit Raja Grafindo Persada, Cetakan keempat, Jakarta, 1997.

Sri Rahayu, Ani, Pengantar Kebijakan Fiskal, Penerbit Bumi Aksara, Jakarta, 2010.

Soemitro, Rochmat, Pajak Ditinjau Dari Segi Hukum, PT. Eresco, Cetakan kedua, Bandung, 1991.

Asas-Asas Hukum Perpajakan, Badan Pembinaan Hukum Nasional Departemen Kehakiman, Jakarta, 1991.

Soekanto, Soerjono, Penelitian Hukum Normatif, Suatu Tinjauan Singkat, Cetakan Kedua, Penerbit CV. Rajawali, Jakarta, 1986.

Syaukani HR, Afan Gaffar, dan M Ryaas Rasyid, Otonomi Daerah Dalam Negara Kesatuan, Penerbit, Pustaka Pelajar, Jogyakarta, Cet I, 2002.

Sukardji, Untung, Sebuah Analisis Konstruktif Perubahan Undang-Undang Pajak Pertambahan Nilai 1984 dengan UU Nomor 18 Tahun 2000, PT. RajaGrafindo Persada, Cet I, Jakarta, 2001.

Tanya, Bernard L., Yoan N. Simanjuntak, Markus Y. Hage., Teori Hukum, Strategi Tertib Manusia Lintas Ruang dan Generasi, Genta Publishing, Cet. III, Yogyakarta, 2010.

Widjaja, HAW., Otonomi Daerah dan Daerah Otonom, Penerbit RajaGrafindo Persada, Cet I, Jakarta, 2002. 
Undang-Undang No. 32 Tahun 2004 tentang Pemerintahan Daerah

Undang-Undang No. 33 Tahun 2004 tentang Perimbangan Keuangan Antara Pemerintah Pusat Dan Pemerintah Daerah

Undang-Undang No. 28 Tahun 2009 tentang Pajak Daerah Dan Retribusi Daerah

Undang-Undang No. 8 Tahun 1983 Tentang Pajak Pertambahan Nilai Atas Barang dan Jasa dan Pajak Penjualan Atas Barang Mewah sebagaimana telah diubah dengan Undang-Undang Nomor 42 Tahun 2009.

Mahkamah Konstitusi, Putusan Nomor 77/PUU-VIII/2010 Mengenai Pengujian UU Nomor 12 Tahun 1985 tentang pajak Bumi dan Bangunan

Mahkamah Konstitusi, Putusan Nomor 52/PUU-IX/2011 Mengenai Pengujian UU Nomor 28 Tahun 2009 tentang Pajak Daerah dan retribusi Daerah.

http://id.wikipedia.org/wiki/Otonomi daerah, diunduh tanggal 25 Juli 2012. 